\title{
A STRATEGIC APPROACH TO INNOVATION
}

\author{
DOI: 10.17261/Pressacademia.2017.491 \\ JMML-V.4-ISS.3-2017(11)-p.290-300
}

\section{Ebru Dogan}

Istanbul University, Faculty of Economics, Department of Business Administration, İstanbul, Turkey. ebruseng@istanbul.edu.tr

\section{To cite this document}

Dogan, E., (2017). A strategic approach to innovation Journal of Management, Marketing and Logistics (JMML), V.4, Iss.3, p290-300.

Permemant link to this document: $\mathrm{http} / / /$ doi.org/10.17261/Pressacademia.2017.491

Copyright: Published by PressAcademia and limited licenced re-use rights only.

\begin{abstract}
Purpose- The aim of this study is to examine the concept of strategic innovation - which includes a strategic approach to innovation - within the framework of its antecedents, the elements forming it and the advantages provided to the company.

Methodology- Theoretical analysis: Innovation has been analyzed from a strategic point of view by examining the current literature extensively.

Findings- Along with the impact of globalization and the emerging new technologies, companies must manage the change by perceiving it as an opportunity to be able to sustain, grow and compete in a rapidly changing environment and respond to change with innovation. Innovation reflecting the perspective of companies on change creates value through change. In today's business world, there are true opportunities for the ones that can manage the process of change well. At this point, a company desiring to create value and maintain the sustainable competitive advantage should use innovation strategically.

Conclusion- A strategic perspective on innovation leads the organization to look at the whole system beyond the product and the process in order to create value. Successful companies in innovation deal with it in a holistic and systematic approach by developing a fully integrated innovation strategy with its mission and objectives and by making organizational culture and organizational systems compatible with the strategy. Strategic innovation is a future-oriented concept that contains a creative discovery. The strategic consideration of innovation involves the use of appropriate strategic management techniques to increase the impact of innovation activities on growth and performance of the company.
\end{abstract}

Keywords: Innovation, strategy, strategic innovation, strategic management, change.

JEL Codes: M10, M13

\section{INTRODUCTION}

Today's business environment has changed qualitatively from many directions since the late 1980s. An economy based on manufacturing and commodities has quickly become an economy where information, services, support and distribution issues are more important. This change has increased the importance of information workers being a new class of wealthy, educated and mobile people who see themselves as free in the seller's market. Along with the information age, the acceleration of technological change in almost every sector, besides the domination of information technologies, has created entirely new businesses, they have destroyed those who cannot adapt to this change and have created an ever increasing demand for innovation. New product, process, and distribution technologies provide powerful levers for creating competitive value. More companies have realized the importance of disruptive technologies; innovation has attained a potential that invalidates a product line or even an entire business division. Another fundamental trend has become the decoupling of consumer and labor markets. Consumer expectations are changing very rapidly and even similar customer groups can have very different preferences for the products they want to buy. Today, new technology has made it easier, faster and cheaper to reach target micro markets that were physically impossible and too expensive to reach in the past. Moreover, this tendency is self-sustaining and the ability of a company to serve sub-markets is accompanied by an increasing demand from customers for more specific presentations (Nadler\&Thusman 1999: 48,49). 
Such changes in the competitive environment affect many companies unwittingly due to the features that can appear at any time and can have important consequences for the development and management of products, markets and organizational capabilities. They have to get away from monolithic and rigid organizational strategies and practices in such an environment (Ahmed and Shepherd, 2010: 82). These changes in the business environment challenge the basic assumptions about organizational design. While the purpose of historically organizational structures is to institutionalize the stability, the purpose of design in today's organizations will be the institutionalization of change. In this regard, there is a profound change in the purpose and meaning of organizational design (Nadler\&Thusman 1999: 49). Past accomplishments do not guarantee a survival in the long run now. Managing the continuously changing aspect of change is the challenge to strategy. In this context, successful firms are those that can innovate and develop strategically (Ahmed and Shepherd, 2010: 82).

Today, change has become a natural part of the business; however, even more important is the increasing speed of change. The life span of products, processes and technology is rapidly shortening and the critical issue at this point emerges as managing the time. The demands revealed by the time pressure push the companies towards competing, innovating and finding creative ways and methods while doing it.

As a result of this change, firms must strategically use innovation to compete effectively in local and global markets, to gain competitive advantage, to adapt their strategies to changing market and customer demands, to create value and to achieve superior performance (Keupp, Palmié and Gassmann, 2012: 367). In this study, innovation is addressed from a strategic point of view, the basic elements of strategic innovation are examined and the role of strategic innovation for companies in creating value and maintaining sustainable competitive advantage is put forward.

\section{INNOVATION}

The word innovation comes from the Latin, innovare, and is about change. Innovation is a process of creating value from ideas (Tidd and Bessant, 2014: 3).

According to Drucker, "Innovation is the act that endows resources with a new capacity to create wealth. Innovation, indeed, creates a resource. There is no such thing as a resource until man finds a use for something in nature and thus endows it with economic value" (Drucker, 1985: 27).

"An innovation is the implementation of a new or significantly improved product (good or service), or process, a new marketing method, or a new organizational method in business practices, workplace organization or external relations" (OECD-Eurostat, 2005: 45).

When the most successful innovations are analyzed, it is observed that they are the beneficiaries of the change. As a matter of fact, change always provides opportunities for the new and different one. "The discipline of innovation is a diagnostic discipline: a systematic examination of the areas of change that typically offer entrepreneurial opportunities". Systematic innovation means tracking seven sources for innovative opportunity. The first set of sources is included in the business or industry. These are 'the unexpected' which means an unexpected success, failure or an event in outer environment, 'the incongruity' indicating the innovation based on the process need - the changes that cannot follow everyone in industry or market structure. The second set of sources contains the changes apart from the business or industry. These are demographics (population changes) - changes in perception, mood and meaning - and new knowledge (Drucker, 1985: 31,32)

The ability of companies to innovate is not limited to the development of products; it may target four main procedures. These all begin with a 'P': P1 innovation to introduce or improve products; P2 innovation to introduce or improve processes; P3 innovation to define or re-define the positioning of the firm or products; P4 innovation to define or re-define the dominant paradigm of the firm. P4 provides a structured approach in order to analyze the opportunity field for innovation (Francis and Bessant, 2005: 172). The alternatives can be arranged in four dimensions as shown in Table 1 according to the type of change.

Table 1: Dimensions for Innovation

\begin{tabular}{|l|l|}
\hline Dimensions & Type of change \\
\hline Product & Changes in the things (products/services) which an organization offers \\
\hline Process & Changes in the ways in which these offerings are created and delivered \\
\hline Position & Changes in the context into which the products/services are introduced \\
\hline Paradigm & Changes in the underlying mental models which frame what the organization does \\
\hline
\end{tabular}

Source: Tidd and Bessant, 2014: 24 
Pressures on firms to make innovation can come from trajectories (such as technological progress and changes in the economy) or actors (such as shareholders, suppliers, customers and competitors). In order to eliminate the tension between the impairment of the status quo and existing competencies, organization starts to search for opportunities and resources to innovate and build new core competencies. Thus, firm starts an innovation process. Management shapes the nature and activity of the process by dividing the resources into the operational skills and transforming these resources into basic skills that are difficult to imitate for competitors (Sammut-Bonnici and Parautis, 2013: 925,928)

Innovation is any product or service that creates extraordinary value for shareholders, real and sustainable competitive advantages and unique and effective solutions valued by customers. Sustainable competitive advantage can be achieved through the identification, creation and use of unique organizational knowledge, skills and experience that cannot be imitated by the rivals. Organizations must start positioning the innovation as the fundamental capability (Snyder and Deborah, 2003: 6-8).

In a study conducted on innovation leaders in twenty-five sectors, it has been delivered that such firms have drawn away their competitors and displayed a performance over the average stock prices. All the economic growth that has taken place since the eighteenth century can be attributed to innovation. Innovation involves a dynamic goal; effective management if innovation doesn't guarantee the success due to the fact that technology, markets, arrangements and other factors are continuously changing. Successful innovators are interested in developing dynamic talent to change their approach (Tidd and Bessant, 2014: 9).

Companies faced with a complex and uncertain future and operating in such areas as information technology, multimedia and communications need to find a new direction in the 21st century in order to master the competition. They need to manage a radical transformation of the basic framework used in the past including current strategies, structure, culture, competencies and business processes. Organizations should be flexible in order to respond to competition threats coming from their competitors on the one hand and they should still maintain the growth based on their strengths by ensuring a sustainable working environment on the other. In this regard, it is necessary to ensure more effective operation of managers, to develop creativity through innovation management and to think on global scale while acting locally (Kodama, 2003: 235).

Although innovation has different meanings, it manifests itself in different ways in a similar way. These formats are derived from the variety of meanings implied. Formats are generally divided into two categories; those under the control of an operator and those outside the scope of company or affecting each other. Strategic innovation forms the types of innovation that are under the control of the enterprise together with product and process innovation (Figure 1). Any form of innovation occurs when value is added to produce a hitherto novel outcome (Ahmed and Shepherd, 2010: 7-11).

-Product innovation is the most visible manifestation of innovation process. The products consumed by the market represent the visible traces of the innovation process or action. New products are the result of the innovation process and product innovation can be focused on technology or marketing.

-Process innovation expresses the change in execution of the organization activities of an enterprise. How a company organizes and manages its functions can be a result of the technological improvements or it may come from the acceptance of the latest structural or operational form.

- Strategic innovation usually involves a major adaptive change in the firm's business model or the adoption of a new business model. They can sometimes be driven by innovations that occur within the organization such as strategic change, product and process innovations or by external innovations and challenges. External strategic changes such as mergers are the most common manifestations of strategic innovations. Also, internally focused strategic innovations generally involve structurally remodeling.

- Social innovation is the result of many factors that come together in order to drive a society that is constantly changing towards a new direction (e.g.: heightened awareness of atmospheric pollution has made society environment conscious and this in turn led to social innovation).

- Political innovation is often observed in the form of legislation, institutional reform, social orientation and governance. The changes that take place in the political arena often have important consequences for the direction and development of the society as well as the organizations.

-In philosophical innovation, new philosophical thought has profound influence on society, promotes the knowledge of the society and enables the community to be guided by defining what is right and wrong.

Companies have now realized that business management is not only behavioral but also an intellectual discipline and that different thinking is a necessary condition to be different (Styles\&Goddard, 2004: 65): 


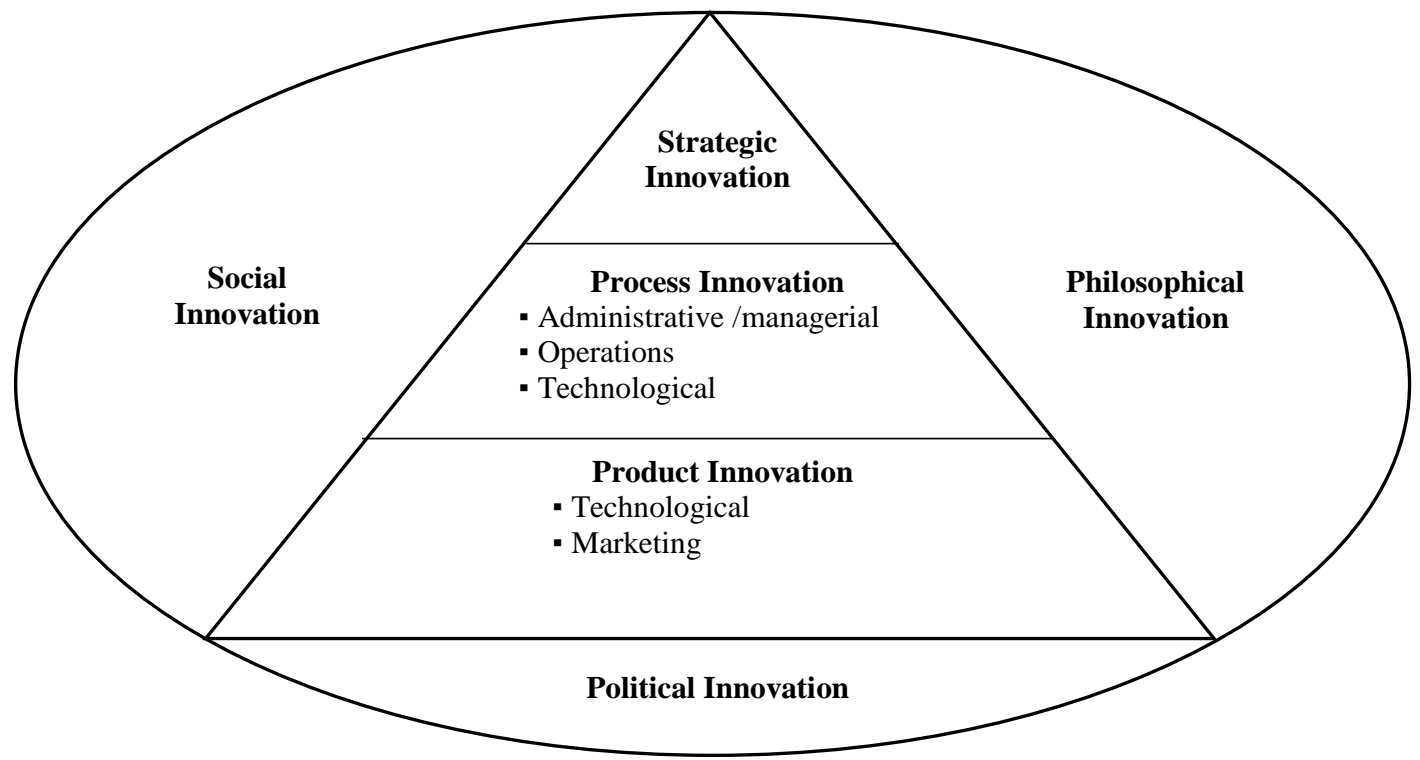

Figure 1: Innovation Formats

Source: (Ahmed and Shepherd, 2010: 7)

\section{STRATEGIC INNOVATION}

\subsection{The Concept of Strategic Innovation}

The competitive environment that companies face today is very different from the competitive environment that created the concept of strategy fifty years ago. However, the rapidly changing strategy environment has become a power that partially depresses some traditional strategy concepts such as industry structure analysis while evoking a lot of new thoughts at the same time. Indeed, this context changing for the strategy has encouraged many new ideas on strategy content. The new themes in the strategy world include foresight, knowledge, competencies, coalitions, networks, extramarket competition, ecosystems, transformation and renewal. In order to maintain their existence in an "innovate or die" environment of the new economy, companies must develop a new strategy, which is highly important for them (Hamel, 1998: 9,10)

A new competitive situation called "hyper-competition" emerged in the 90's. Hyper competition is a structure in which the core competitive success factor is to constantly develop new products, processes and services with increasing functionality and performance for customers. There are also increasing technological pressures on firms. It has been acknowledged that the technological life cycles in some industries have declined compared to previous times. New technologies have a strong competitive influence and therefore technological dynamics will affect the competitive dynamics and strategy of companies. Organizations should be more innovative and think proactively in their strategic management (Drejer, 2006: $143,144)$. At the same time, a company should try to institutionalize innovation by establishing appropriate cultures, structures, incentives, systems and processes that will realize innovation as a part of everyday work (Markides, 1997: 22).

In recent years, widespread researches into scientific and managerial conception of strategy and innovation have been observed. Nevertheless, most of these researches are either focused on strategy or innovation; so that strategy and innovation have evolved considerably separately in the schools of thought. In this context, the strategy literature is primarily focused on the level of the institution and the business units while the innovation literature is mostly focused on 
the product level. However, researchers have tackled the innovation and corporate strategy together unlike the traditional tendency in recent years. In this regard, strategic innovation can be expressed as the implementation of innovation on corporate strategy (Schlegelmilch, Diamantopoulas and Kreuz, 2003: 118).

The strategic management of innovation indicates an important component of the corporate strategy and an important factor that has a significant contribution to a company's competitive advantage. For this reason, the strategic management of innovation has become a fundamental issue in the field of strategic management. An innovation can be a new product or service, a new production process technology, a new structure or administrative system or a new plan or program pertaining to organizational members (Keupp et.al.,2012: 367). "The field of strategic management, deals with the major intended and emergent initiatives taken by general managers on behalf of owners, involving utilization of resources to enhance the performance of firms in their external environments" (Nag, Hambrick and Chen, 2007:942). In this context, the strategic management of innovation is concerned with the use of appropriate strategic management techniques in order to increase the effect of firm's innovation activities on firm's growth and performance (Keupp et.al., 2012: 368).

Innovation has traditionally focused on products and processes, and then it has attracted attention as an area that will provide significant gains regarding innovation; however, the combination of product, process and distribution hasn't reflected the sufficient potential for organizational innovation. Nadler and Thusman have stated that the successful organizations of the future are those who will develop extraordinary skills to innovate in the areas of strategy development and organizational design. If the most critical feature of the new business environment is the increasing speed of change, the ability to develop and implement new strategies and organizational designs quickly and creatively will become an important source of competitive differentiation (Nadler and Thusman 1999: 52). The developments experienced over the course of 20 years also confirm these opinions.

Strategy deals with the essential issues of maintaining the entity's existence, represents the new activities and areas of interests and addresses the unusual affairs for the organization (Drejer, 2006: 146). In a world where discontinuity is dominant, the strategic innovation is perceived as a key to creating wealth and as the only way to combat resource disadvantages for new entrants of the market and to maintain success (Hamel, 1998: 8). In a turbulent economic environment characterized by radical changes in a short time, it is essential for the enterprise to have the ability to develop and play a different game. Developing a unique strategy requires learning at a high level of innovation, proactivity, calculated risk taking and analysis of the changes that occur in customer preferences and behaviors of competitors (Preda, 2013: 608). Companies must focus more on strategic innovation that integrates and even transcends all dimensions of innovation in order to create sustainable growth (Moeller, Stolla and Doujak, 2008: 14).

There are different definitions about strategic innovation in the literature. Accordingly;

Strategic innovation is the redesigning capacity of a firm in a way to create new values for customers over the existing industry model and to generate new wealth for all stakeholders (Hamel, 1998: 8).

Schlegelmilch et.al. describes strategic innovation as "the fundamental reconceptualization of the business model and the reshaping of existing markets (by breaking the rules and changing the nature of competition) to achieve dramatic value improvements for customers and high growth for companies". There are three main factors in this definition. These factors are as follows; reconceptualization of business model (reanswering such questions related to business model "in which business line we are in", "who are our customers", "how can we create value"), reshaping the existing markets and creating value for customers (Schlegelmilch et.al., 2003: 118,119).

According to Drejer, "Strategic innovation is the ability to create and revitalize the business idea and concept of the company by changing both the market of the company and the competencies and business system of the company. In this way, strategic innovation is concerned with developing the entire company" (Drejer, 2006: 144).

According to Markides, all companies in an industry have to decide on three main issues at strategic level: 1) Who will be our customers?, 2) What products and services should we offer to target customer? and 3) How should we offer these products and services?. In short, the answers of "who-what-how" questions constitute the strategy of every enterprise. A strategic positioning map for an enterprise shows the answers to these questions and each company has to make choices that will answer these questions. While some companies may choose to focus on specific customer segments and offer specific products and services, others prefer to be global players and offer related products and services. Some companies may even choose a specific technology or distribution method. However, a specific industry positioning map is filled over time. For instance, most of the possible customer segments have been considered; most products and services have been offered; the most common distribution or production methods or technologies have been used (Markides, 1997: 11,12).

Strategic innovation takes place when an enterprise establishes gaps in its industry positioning map and decides to bridge these gaps. The gaps express 1) newly emerged customer segments or those ignored by competitors, 2) newly emerged customer needs or the existing customer needs that aren't well-serviced by rivals and 3) new production, presentation and 
distribution methods of existing or new products and services for current or new customer segments. While the gaps may occur due to such reasons as changing customer pleasures and preferences, changing technologies and changing governmental policies etc., they can also be proactively created by outer changes or the company (Markides, 1997: 12; Markides\&Anderson, 2006: 131)

The first requirement to be a strategic innovator is to define these gaps before everyone else. However, being the first one to identify the right gaps does not guarantee success; a company has to use this gap competitively (Markides, 1997: 12). Strategic innovators go after these gaps and find ways to turn them into profitable markets. They find new customers ("new whos"), new products or services ("new whats") and new ways ("new hows") to promote, produce or distribute them (Anderson\&Markides, 2007: 83). In this regard, strategic innovation means for an enterprise to test new strategies with new combinations created about who, what and how questions. Strategically innovative companies discover the process of continuous learning, experiencing and developing new business opportunities, concepts and new strategies related to these three dimensions (Moeller, Stolla and Doujak, 2008: 15). In this context, strategic innovation is the innovation in the creation and implementation of the strategy; new knowledge is the discovery of the unknown to create new markets and a new field of competition (Preda, 2013: 608).

After examining more than thirty companies that challenged the market leader, Markides has uttered that the common element of success is strategic innovation. Significant changes in market share and revenues arise from the fact that the company changes the rules of the game rather than playing better than the competitors. Without any new technological innovation, it is extremely difficult for any company to compete successfully with the established industry leaders or to enter into a new market where resident companies are located. "The strategy that seems to improve the probability of success in those situations is the strategy of breaking the rules -strategic innovation". (Markides, 1997: 9-11).

The idea behind strategic innovation is based on three themes: 1) Strategic managers should consider strategy for both tomorrow and today if they want to continue their success. 2) Different types of organizations are needed to succeed in innovation and effectiveness. Creative thinking is different from traditional analytical thinking. 3) Competition focuses on the concepts and business models that change the rules of competition play rather than product markets and technology (Drejer, 2006: 144).

The basic elements of strategic innovation are as follows (Styles\&Goddard, 2004: 65):

- A firm is seen as a pool of scarce and valuable resources and capabilities that are exploited through a specific business model or strategy.

- High returns are derived not from adapting the same appropriate policies as everyone else, but from industry-wide hard assumptions.

- Inspiration for innovation may come from the feeling that there is no customer satisfaction and no other choice by the business.

- A radical change in operational efficiency creates more value than the incremental improvement.

- Strategy focuses on shaping some aspects of the future environment.

Strategic innovation is different from technological or product innovation. New technologies don't always deliver successful products or new products aren't important strategically. Strategic innovation made in at least one of these three areas of value chain design, conceptualization of customer value and identification of potential customers draws a line under the past implementations. Strategic innovation involves a discovery to create new knowledge and possibilities. Strategic testing is used to test the applicability of new business ideas (Govindarajan\&Trimble, 2004: 69). While managing the strategic testing, a CEO must make choices about structure, staff, systems and culture. These choices together constitute the fundamental rationale of how an organization behaves. At this point, Govindarajan and Trimble (2005) propose the concept of organizational DNA which is constituted by organization's structure, systems, personnel and culture (Govindarajan and Trimble, 2005: 48,49).

\subsection{Sources and Outcomes of Strategic Innovation}

In literature, there are four key forces determined to feed the strategic innovation in an enterprise together; these are culture, processes, people and sources. The outcomes of strategic innovation are customer value and competitive positioning. Schlegelmilch et.al. have proposed Strategic innovation MIMIC Model containing these factors that affect strategic innovation and the outcomes of strategic innovation (Figure 2). 


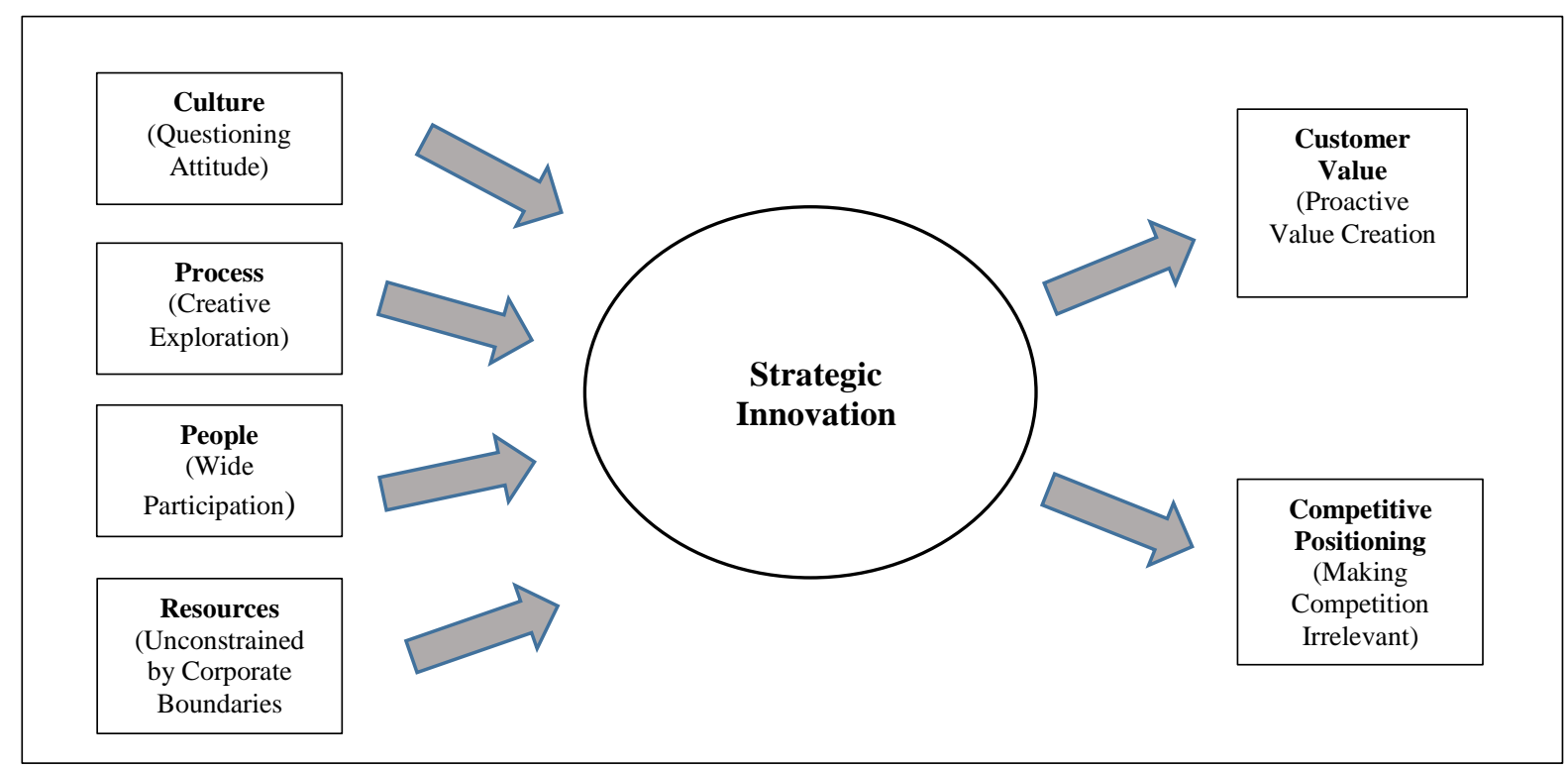

Figure 2 : Strategic Innovation MIMIC Model

Source: (Schlegelmilch et.al., 2003: 127).

- Culture: It is necessary to understand its strong connection with the organizational culture while trying to understand the strategy and its development. "Strategies are both rooted in and partly explained by organization culture". The organizational culture to be formed under the influence of visionary leaders in the organization is one of the most important strategy areas (Clark, 1995: 2). The most important cultural value on which researchers unanimously agree that it is necessary for strategic innovation is the creation of a questioning attitude. A prerequisite for strategic innovation is the identification of dominant mental models that manifest themselves in the organization's culture, routines and non-written codes of conduct. An industry's most dominant mental model is business perception including the assumptions concerning area of competition, customers, suppliers and technology. Companies have to create a culture that challenges traditionalism, exposes the feeling of discovery and encourages decision makers to look at different perspectives. Today, an enterprise can sustain its innovation-focused culture by encouraging project teams with flexible organizational boundaries, creating an environment where ideas and creativity is freely expressed and supporting staff turnover (Schlegelmilch et.al., 2003: 120).

An organizational culture devoted to innovation and openly recognizing the collective nature of innovation efforts will undoubtedly increase innovative success (Panne, Beers and Kleinknecht, 2003: 19) In a global survey of more than 700 publicly traded companies from 17 developed and developing countries' economies, it has been determined that the culture is the most important driver of innovation. A different innovative culture helps to harmonize the innovation approach of an organization with business strategies (Schroeder, 2013: 7,8).

- Processes: Innovation requires the use of structures and systems to support each phase of the innovation process, the allocation of adequate resources to each business cycle and the clear description of responsibilities (Schroeder, 2013:10). The traditional strategy development process is often characterized as an analytical and time-ordered discourse. As a result, strategic planning is criticized for being rule-based, control-oriented and based on many historical examples. These features lead to a general acceptance of dominant business parameters and as a reflection of this, the outcome of the strategic process is limited by existing conditions and opportunities for growth may be overlooked. On the other hand, the strategic innovation process is a process of growth-oriented and future-oriented process involving a creative discovery and therefore, it deliberately surpasses existing business boundaries. So, growth opportunities neglected by traditional processes can be utilized by discovering the areas where there is no rivalry. The creative strategic innovation process and the traditional analytical strategy process must be combined (Schlegelmilch et.al., 2003: 120,121). 
Wood proposes a simple approach to the question of how firms can achieve repeatable successful strategic innovation: rather than trying to develop a clear, detailed plan of how the innovative organization should work, starting with a big and enthusiastic goal, improvising some steps along with a team to this end and maximizing learning from improvisation (Wood, 2007: 21). A well-thought executive strategy can give an opportunity to make more strategic innovations to a company (Eppink, 1995: 158). This process allows the emergence of new procedures and methods embodying the wisdom of the organization and can encourage future recurrent innovation (Wood, 2007: 21).

Innovation processes are based on innovative ways of making innovation that occur with less routine planning used for more strategic innovation. In his work, Wood brings out successful implementations of a five-step process in order to initiate constant strategic innovation. However, the key to understand these steps is to realize the importance of improvisation. Leaders need to understand the difference between improvisational change and planned change to support effective strategic innovation processes. The five-step process used by successful companies requires continuous learning from below points in order to reveal a vague yet powerful goal, the first innovation experiments that have been largely improvised and effective strategic innovation routines. The process is as follows in companies making innovation (Wood, 2007: 21-27):

1. Accepting change as indispensable. Leaders recognize the crisis that the organization is facing and help others understand and confront it.

2. A commonly-shared strong goal is to develop strategic intent. The goal should have an emotional attraction and so it should be easily supported by people. Benefits must be open to society, not just for the company. The goal is the main idea to advance the first innovations.

3. A person who is motivated by a strong goal makes a new and different innovation without following any well-defined rules or methodology.

4. Some innovations seem to succeed and people copy the first innovation processes, adapt them to new uses and thus create new innovations.

5. Development and operation of strategic innovation routines. Innovation processes based on the improvised methods of making innovation become routine. Leaders formalize some elements to improve efficiency and clarity.

- People: Innovative organizations are aware of the fact that the innovator is not the organization but the people who make the organization innovative with their thoughts and movements (Dobni, 2008: 43). A widespread criticism in the literature is that the strategy is typically formulated by senior executives in an organization. However, their experience is valuable only to the extent that future is similar to the past. In industry the terrain is changing so fast that experience becomes irrelevant (Hamel, 1996: 48). One of the factors strongly associated with successful innovation is the ability to establish strong relations with internal and external stakeholders in order to cooperate with them or to incorporate them into the innovation process (Schroeder, 2013: 7,8). In this framework, the strategy creation process is strong only when the dialogue related to strategy is pluralistic and broadly participatory by overcoming all functional and hierarchical limits. Anyone whose supports are needed for the successful implementation of a new strategy should be included in its creation process. In the context of strategic innovation, representatives from R \& D, sales, marketing, finance and other basic functions must play an active role in developing strategy. Additionally, the different perspectives that young people, newly-recruited people in business and stakeholders around a business can bring to creation of a strategy should become more effective. Creating a dialogue that transcends the organizational and industrial boundaries of the strategy significantly increases the likelihood of emerging new strategic insights (Schlegelmilch et.al., 2003: 122).

- Resources: One of the main tasks of the managers is to procure, develop and appropriately distribute the resources of an organization. According to traditional logic, a company must use its existing resources (assets and capabilities). Superior business performance can be achieved when these company-specific resources are rare, valuable, unique, and have no equivalent substitutes. According to this resource-based view, companies see the job opportunities in terms of their existing assets and capabilities and they ask the following question: what can we do best if we accept what we have as data? Thus, internal systems and capabilities of focusing should be matched with the external opportunities. A great deal of the literature on strategic innovation criticizes the inward approach focused on these corporate capabilities because it limits the opportunity horizon of the business (Schlegelmilch et.al., 2003: 122). The opportunity to make innovation depends on the opinion on strategy and company's success. Hamel and Prahalad have expressed their view of strategy as "stretch" against the traditional strategy view, which is the fit between the opportunities/threats and the strengths/weaknesses. Successful companies don't always comply with the 'fit' criterion and most of them can benefit from the resources of other companies by entering into strategic alliances instead of doing everything through their own means (Eppink, 1995: 159). In this sense, strategic innovators are violating the paradigm of matching internal resources with external opportunities and are asking the following question: What would we do if we were starting a new? They choose to 
create and maintain strong relations that provide stakeholders network and complementary assets, capabilities, products and services (Schlegelmilch et.al., 2003: 123). Today, however, technology is a very important resource for many organizations and they should manage this resource for competitive advantage and integrate it with the strategy of the firm (Burgelman, Christensen and Wheelwright, 2004: 2).

Accordind to Pitt and Clarke, "strategic innovation is the purposeful orchestration and directed application of organizational skills and knowledge". Effective strategic management requires the deployment of this 'architectural' ability, which is primarily an organizational skill, not a technical skill. Effective strategic management is basically the development of collective information and the regulation of leverage. Business-specific 'architectural' skill is primarily an organizational and managerial competence and it is undoubtedly crucial for success in the long run (Pitt and Clarke, 1999: 301,312). Numerous studies have emphasized the importance of innovation as a critical success factor in business performance. Leading global companies such as Apple Inc., $3 G$ and Procter \& Gamble owe their business success to the continuous registration of their successful innovations. The available evidence shows that the most successful companies in the innovation field approach to innovation with a holistic and systematic approach by developing a fully integrated innovation strategy with the mission and objectives of the business and by according the organizational culture and organizational systems with strategy (Schroeder, 2013: 6)

Surveys show that monitoring a clearly defined innovation strategy is one of the preconditions for success in innovation. However, many enterprises cannot afford to spend time and resources in developing ideas that are tangential to the organizational missions or their main objectives. Creating a strategy defines a broad scope within which innovations that present business value can be developed; the strategy is a series of decisions concerning where the business will play and how to win in order to maximize long-term value. Therefore, innovation strategy must depend on organizational mission, main values and business goals. It will define the goals and objectives of innovation, the acceptable ways to fulfill them and the responsibilities for developing solutions in specific areas. This strategy not only helps to develop value-creating innovations, it also motivates employees to find innovative solutions to specific organizational issues and subjects (Schroeder, 2013: 9).

A strategic perspective on innovation and strategic thinking will motivate the organization to look at the entire system beyond the product and the process to provide value to customer. Strategy and innovation is a motivation to promote participation and to produce value-creating innovations and its reward is profit and sustainability (Stewart and Fenn, 2006:182). Success in creating customer value is largely due to proactive market interpretation rather than tracking customer recommendations. Strategic innovation is concerned not with making marginal or incremental improvements, but with making a significant leap about value. Thus, strategically innovative companies proactively create value and provide new solutions to customers (Schlegelmilch et.al., 2003: 119).

Innovation means creating value via change. However, it can be risky to change work in a random way; if the company does not know where it is going, it can go somewhere different. In this respect, there is a clear sense of direction at the heart of effective innovation management: how and where innovation will help us progress? Another reason why an innovation strategy is a good idea is that it clarifies the question of - even the best equipped organization cannot do everything and therefore for what and why will it spend its rare resources?. At this point, innovation strategy can give a road map for change. However, there is no certainty that the new technology will really work and that the expected market will come into being because there is a vague future; the actions of competitors or governments sometimes happen unexpected for the enterprise. Of course, it is useful for a company to have a road map in order to reach the point it wants to arrive; but the fact that it opens to change shouldn't be ignored. Strategy is also related to determining a vision about future. Three main elements in creation of innovation strategy are as follows: strategic analysis- exploring where we could innovate; strategic choice- choosing between different options; strategic implementation- planning to make innovation happen (Tidd and Bessant, 2014: 21,22).

Strategically innovative firms follow competition by changing the traditional competitive mentality expressed as making an effort to exert superior performance than their competitors; however, they use it as benchmark. They don't follow any strategy as the competitors apply, they make competition irrelevant by offering fundamentally new and superior value. Strategic innovators first identify the total solution that buyers want to achieve when choosing a product or service and then look for complementary product and service offerings outside the industry to discover the value in the dark (Schlegelmilch et.al., 2003: 124-127). Process innovation and product innovation are the predominantly used methods to maintain the company's competitive position. However, in order to strengthen the growth potential of a company, it is desirable to create new business - which is another strategic option - and to create new market space through new business concepts. It can be focused on a new set of customer needs, addressed to new or insufficient customer segments or new methods of offering value can be presented (Moeller et.al., 2008: 10,11). 


\section{CONCLUSION}

Along with the information age, the dominance of information technology and rapid technological change in almost every sector have created completely new businesses, have destroyed those who cannot adapt to this change and have made a constant need for innovation. Today, stakeholder expectations are changing rapidly and the areas of responsibility of the company are expanding day by day. The companies faced with a complex and uncertain future need to find a new direction to maintain their existence, compete and sustain their achievements. The life span of products, processes and technologies is rapidly shortening and the demands revealed by the time pressure push companies to find new creative ways and methods while making innovation. In this regard, they need to be flexible enough to respond to any change that may arise in the environment and develop a strategic view of innovation in order to sustain their existence.

Today, the rapidly changing competitive environment has become a force that motivates new ideas while partially reducing the value of traditional strategy concepts. A company should try to institutionalize innovation by creating the appropriate culture, structure, systems and processes that enable the emergence of innovation. Companies should focus more on strategic innovation that integrates all dimensions of innovation to ensure sustainability, long-term profit, competitive advantage and diversification. A strategic perspective on innovation will guide the organization to look at the whole system beyond product and process, ensure motivation to generate innovations that will encourage participation, strategy and create value and will be the key to sustainable competitive advantage for companies.

\section{REFERENCES}

Ahmed P.K. \& Shepherd C.D. 2010, Innovation Management: Context, Strategies, Systems and Processes, 1st ed., Harlow: Pearson Education

Anderson J. \& Markides C. 2007, "Strategic Innovation at the Base of the Pyramid", MIT Sloan Management Review, vol.49, no.1, pp. 83-88.

Burgelman R.A., Christensen C.M. \& Wheelwright S.C. 2004, 4th ed., Strategic Management of Technology and Innovation, Singapore:McGraw Hill.

Clark, J. 1995, Managing Innovation and Change: People, Technology and Strategy, Thousand Oaks: Sage Publications.

Dobni, C. B. 2008, "The DNA of Innovation", Journal of Busıness Strategy, vol.29, no.2, pp.43-50.

Drejer, A. 2006, "Strategic Innovation: A New Perspective on Strategic Management", Handbook of Business Strategy, vol.7, no.1, pp.143147.

Drucker, P. F. 1985, Innovation and Entrepreneurship, London: Hinemann.

Eppink, E. J. (1995). Strategic Innovation, Joumal of Strategic Change, vol.4, pp.155-160.

Francis, D. \& Bessant, J. 2006, “Targeting Innovation and Implications for Capability Development", Technovation, vol.25, no.3, pp.171-183.

Govindarajan, V. \& Trimble, C. 2004, "Strategic Innovation and the Science of Learning", MIT Sloan Management Review, vol.45, no.2, pp.67-75.

Govindarajan, V. \& Trimble, C. 2005, “Organizational DNA for Strategic Innovation”, California Management Review, vol.47, no.3, pp. 47-76.

Hamel, G. 1996, "Strategy as Revolution”, Harvard Business Review, vol.74, no.4, pp.69-71.

Hamel, G. 1998, "Strategy Innovation and the Quest for Value", Sloan Management Review, vol.39, no.2, pp.7-14.

Keupp, M. M., Palmié, M. \& Gassmann, O. 2012, "The Strategic Management of Innovation: A Systematic Review and Paths for Future Research", International Journal of Management Reviews, vol.14, pp.367-390.

Kodama, M. 2003, "Strategic Innovation in Traditional Big Business: Case Studies of Two Japanese Companies", Organization Studies, vol.24, no.2, pp.235-268.

Markides, C. 1997, "Strategic Innovation", Sloan Management Review, Spring, vol.38, no.5, pp.9-23.

Markides, C. C. \& Anderson, J. 2006, "Creativity Is Not Enough: ICT-enabled Strategic Innovation", European Journal of Innovation Management, vol.9, no.2, pp.129-148.

Moeller, M., Stolla, C. \& Doujak, A. 2008, Strategic Innovation: Building New Growth Businesses, Neuwaldegg.

Nadler, D. A. \& Tushman, M. L. 1999, "The Organization of the Future: Strategic Imperatives and Core Competencies for the 21st Century", Organizational Dynamics, vol.28, no.1, pp.45-60.

Nag, R., Hambrick, D. C. \& Chen, M. 2007, "What Is Strategic Management, Really? Inductive Derivation of a Consensus Definition of the Field", Strategic Management Journal, vol.28, no.9, pp.935-955. 
OECD \& Eurostat. 2005, Oslo Manual: Guidelines For Collecting and Interpreting Innovation Data, Third Ed., OECD Publishing.

Panne, G., Beers, C. \& Kleinknecht, A. 2003, "Success and Failure of Innovation: A Literature Review", International Journal of Innovaiın Management, vol.7, no.3, pp.1-30.

Pitt, M. \& Clarke, K. 1999, "Competing on Competence: A Knowledge Perspective on the Management of Strategic Innovation", Technology Analysis \& Strategic Management, vol.11, no.3, pp.301-316.

Preda, G. 2013, "The İnfluence of Entrepreneurial Orientation and Market-Based Organizational Learning on The Firm's Strategic İnnovation Capability", Management \& Marketing Challenges for the Knowledge Society, vol.8, no.4, pp.607-622.

Sammut-Bonnici, T. \& Paroutis, S. 2013, “Developing a Dominant Logic of Strategic Innovation”, Management Research Review, vol.36, no.10, pp.924-938.

Schroeder, H. 2013, "Strategic Innovation for Business Performance: The Art and Science of Transformation", Technology Innovation Management Review, September, pp.6-12.

Schlegelmilch, B. B., Diamantopoulas, A. \& Kreuz, P. 2003, "Strategic Innovation: The Construct, It's Drivers and Its Strategic Outcomes", Journal of Strategic Marketing, vol.11, pp.117-132.

Snyder, N. T. \& Deborah, L. D. 2003, Strategic Innovation: Embedding Innovation as a Core Competency in Your Organization, San Francisco: Jossey Bass.

Stewart, I. \& Fenn, P. 2006, "Strategy: The Motivation for Innovation", Construction Innovation, vol.6, pp.173-185.

Styles, C. \& Goddard, J. 2004, “Spinning the Wheel of Strategic Innovation”, Business Strategy Review, vol.15, no.2, pp.63-72.

Tidd, J. \& Bessant, J. 2014, Strategic Innovation Management, West Suusex: John Wiley\&Sons.

Wood, R.C. 2007, “How Strategic Innovation Really Gets Started”, Strategy \& Leadership, vol.35, no.1, pp.21-29. 